\title{
Relationship between Profile of Rural Youth and Attitude towards Village Development Activities
}

\author{
M.S. Anarase*, D.D. Suradkar and V.B. Kamble
}

Department of Extension Education, College of Agriculture, Latur 413-512, India

*Corresponding author

Key w o r d s
Rural youth, Profile,
Attitude, Relationship,
Village development
activities

The present study was conducted in Latur district from Marathwada region of Maharashtra, with an objective to analyze relationship between profile of rural youth and attitude towards village development activities. For this study random sampling method was used to select the district, talukas and villages.10 respondent from each village were selected thus, Total 120 respondents selected for the study and Ex-post Facto research design was used for research study. Results revealed that, majority $(61.66 \%)$, of respondent were middle age group, 36.67 per cent of them were educated up to post graduate level, 62.50 per cent belongs Hindu religion, 57.50 per cent belongs Nuclear family type, 54.17 per cent of respondents had medium family size. Whereas almost 60.83 per cent had medium annual income (1.01 to 6.70 Lakh Rs.), had 60.00 per cent respondents had medium use of sources of information, 70.83 per cent of them medium extension contact and 67.50 per cent of respondents had medium achievement motivation. Result of correlation coefficient (r) showed that independent variables namely age, education, religion, family type, family size, annual income, use of sources of information, extension contact, and achievement motivation had found to be positive and highly significant relationship with attitude of rural youth towards village development activities.

\section{Introduction}

Youth are one of the greatest assets that any nation can have. Not only are they legitimately regarded as the future leaders, they are, potentially and actually the greatest investment for a country's development. They serve as a good measure of the extent to which a country can reproduce as well as sustain itself. The extent of their vitality, responsible conduct and roles in society is positively correlated with the development of their country. The youth also constitute the major resource base for any country that want to embark on any meaningful rural development projects. Lagun (2002) observes that investment in the youth is the only way to ensure the future growth and development of any country. The contribution of the youth is essentially important in the development of rural areas. The youth are essential human beings in the development of rural areas. The development of rural areas in developing countries is the root of economic upliftment for these nations. Therefore the present study entitled, "Relationship between Profile of 
Rural Youth and Attitude towards Village development activities." was undertaken by following specific objectives.

To study the profile of rural youth.

To ascertain the relationship between profile of rural youth with their attitude towards village development activities.

\section{Materials and Methods}

The study was conducted in Marathwada region of Maharashtra State. From this region Latur district was randomly selected on the Lottery basis for research purpose. From the selected district three talukas viz, Latur, Chakur and Nilanga were selected randomly from the Latur district. For the purpose of the study, four villages selected from each selected tahsils were randomly selected. Thus, total 12 villages were selected for the study. From each selected village 10 respondents were selected randomly. Thus, total 120 respondents comprised for the study. Ex-postfacto research design was adopted for research purpose.

Keeping in the view the objectives of the study a structured interview schedule was prepared. After finalizing the research design and interview schedule, the data were collected by using the personal interview method. Collected data were classified, tabulated, analyzed by using frequency, percentage, Correlation coefficient were used for analysis.

\section{Results and Discussion}

\section{Profile of rural youth}

\section{Age}

It was clear from the Table 1 that, more than half 61.66 per cent of the youth belong to the 'middle' age group, followed by 21.67 per cent of the youth are 'young' age and 16.67 per cent of youth from 'old' age group.

\section{Education}

Data presented in Table1 revealed that, majority $(36.67 \%)$ of the youth belonged to Post graduate level followed by Graduate level $(35.00 \%)$, higher secondary education $(27.50 \%)$, middle education $(00.83 \%)$, and none of them were Illiterate, Primary education, and $\mathrm{Ph}$. D.

\section{Religion}

Results pertaining from Table 1 indicate that, 62.50 per cent of the youth belongs to the Hindu religion, followed by 22.50 per cent of the youth from Muslim religion, 11.67 per cent of Buddha, 03.33 per cent of Jain, and none of them were Christian, Sikh, and others

\section{Family type}

It is observed from the Table 1 that, more than half 57.50 per cent of the youth belongs to nuclear family and 42.50 per cent belongs to joint family.

\section{Family size}

Data pertaining to the family size presented in Table 1 shows that, 54.17 per cent of the youth belongs to medium family size, while 38.33 per cent and 07.50 per cent were small to big family size.

\section{Annual income}

It was elucidated from the Table 1 that, majority $(60.83 \%)$ of youth had medium annual income (1.1 to 6.7 Lakh Rs.) followed by $(22.50 \%$ ) had low annual income (up to 1 Lakh Rs.) and (16.67\%) had high annual income (Above 6.71 Lakh Rs.) per year. 


\section{Use of sources of information}

The data with regard to use of sources of information presented in Table 1 indicated that, more than half 60.00 per cent of the youths had medium use of sources of information while 20.83 per cent of them had more use of sources of information.

Only 19.17 per cent had less use of sources of information.

\section{Extension contact}

The information in respect of Extension contact of the rural youth is presented in Table 1 revealed that, majority $(70.83 \%)$ of youth had medium level of extension contact followed by (17.50\%) and (11.67\%) of rural youth had high to low extension contact.

\section{Achievement motivation}

It is observed from Table 1 that, more than half 67.50 per cent of respondents had medium achievement motivation, while 20.00 per cent had high achievement motivation and only 12.50 per cent of them were found in low achievement motivation category.

\section{Relationship between profile of rural youth with their attitude towards village development activities}

\section{Age and attitude}

The data in the table 2 observed that, there was a positive and highly significant correlation between age and attitude of rural youth towards village development activities.

It means that level of attitude was depending on the age of rural youth.

It can be inferred that level of attitude was increasing with increase in age of respondents due to which age might have established positive and highly significant relationship with attitude.

The findings of the study were similar to that of Olujide (2008), Angba et al., (2009), Adesope et al., (2010), Kitturmath et al., (2014), Gbolagade et al., (2014).

\section{Education and attitude}

The data in the table 2 observed that, there was a positive and highly significant correlation between education and attitude of rural youth towards village development activities.

It can therefore, be inferred that Education had increase fairly high literacy level of the respondents with its possible influence on attitude of rural youth towards village development. Educated youth develop more access to extension agencies, mass media, development organizations, decision making ability, participation in extracurricular activities, and inclined to use innovations by taking the high risk.

The level of education also helps to an individual to get himself acquainted with the skills that are required for development. This might be resulted in establishing a positive and significant relationship of education with attitude.

The findings reported by Uddin et al., (2008), Adesope et al., (2010), Kitturmath et al., (2014).

\section{Religion and attitude}

The data in the table 2 pointed out that, there was a positive and highly significant correlation between religion and attitude of rural youth towards village development activities. 
Table.1 Distribution of respondents according their profile

\begin{tabular}{|c|c|c|c|}
\hline \multirow[t]{2}{*}{ SI. No } & \multirow[t]{2}{*}{ Category } & \multicolumn{2}{|c|}{ Respondents ( $N=120)$} \\
\hline & & Frequency $(\mathbf{F})$ & Percentage $(\%)$ \\
\hline 1. & Age & & \\
\hline 1. & Young (up to 19 years) & 26 & 21.67 \\
\hline 2. & Middle (20 to 26 years) & 74 & 61.66 \\
\hline 3. & Old (Above 27 years) & 20 & 16.67 \\
\hline 2. & Education & & \\
\hline 1. & Illiterate & 00 & 00.00 \\
\hline 2. & Primary Education $\left(1^{\text {st }}-7^{\text {th }}\right)$ & 00 & 00.00 \\
\hline 3. & Middle Education $\left(8^{\text {th }}-10^{\text {th }}\right)$ & 01 & 00.83 \\
\hline 4. & Higher secondary Education $\left(11^{\text {th }} \& 12^{\text {th }}\right)$ & 33 & 27.50 \\
\hline 5. & Graduate & 42 & 35.00 \\
\hline 6. & Post Graduate & 44 & 36.67 \\
\hline 7. & Ph. D. & 00 & 00.00 \\
\hline 3. & Religion & & \\
\hline 1. & Hindu & 75 & 62.50 \\
\hline 2. & Muslim & 27 & 22.50 \\
\hline 3. & Buddha & 14 & 11.67 \\
\hline 4. & Jain & 04 & 03.33 \\
\hline 5. & Christian & 00 & 00.00 \\
\hline 6. & Sikh & 00 & 00.00 \\
\hline 7. & Others & 00 & 00.00 \\
\hline 4. & Family Type & & \\
\hline 1. & Nuclear family & 69 & 57.50 \\
\hline 2. & Joint family & 51 & 42.50 \\
\hline 5. & Family Size & & \\
\hline 1. & Small (up to 4) & 46 & 38.33 \\
\hline 2. & Medium (5 to 9 ) & 65 & 54.17 \\
\hline 3. & Big (10 and Above) & 09 & 07.50 \\
\hline 6. & Annual Income & & \\
\hline 1. & Low (up to 1 Lakh Rs.) & 27 & 22.50 \\
\hline 2. & Medium (1.01 to 6.70 Lakh Rs.) & 73 & 60.83 \\
\hline 3. & High (Above 6.71 Lakh Rs.) & 20 & 16.67 \\
\hline 7. & Use of Sources of Information & & \\
\hline 1. & Less use (up to 26) & 23 & 19.17 \\
\hline 2. & Medium use (27 to 46 ) & 72 & 60.00 \\
\hline 3. & More use ( $47 \&$ Above) & 25 & 20.83 \\
\hline 8. & Extension Contact & & \\
\hline 1. & Low (up to 17) & 14 & 11.67 \\
\hline 2. & Medium (18 to 23 ) & 85 & 70.83 \\
\hline 3. & High (24 \& Above) & 21 & 17.50 \\
\hline 9. & Achievement motivation & & \\
\hline 1. & Low (up to 26) & 15 & 12.50 \\
\hline 2. & Medium (27 to 34$)$ & 81 & 67.50 \\
\hline 3. & High (35 and Above) & 24 & 20.00 \\
\hline
\end{tabular}


Table. 2 Coefficient of correlation between profile of rural youth with their attitude towards village development activities

\begin{tabular}{|c|c|c|}
\hline Sl. No. & Independent variables & Co-efficient of correlation ( $r$ values) \\
\hline 1. & Age & $0.430 * *$ \\
\hline 2. & Education & $0.444 * *$ \\
\hline 3. & Religion & $0.494 * *$ \\
\hline 4. & Family Type & $0.463 * *$ \\
\hline 5. & Family size & $0.461 * *$ \\
\hline 6. & Annual Income & $0.498 * *$ \\
\hline 7. & Use of sources of information & $0.556 * *$ \\
\hline 8. & Extension Contact & $0.502 * *$ \\
\hline 9. & Achievement motivation & $0.502 * *$ \\
\hline
\end{tabular}

\section{Family type and attitude}

The data in the Table 2 concluded that, there was a positive and highly significant correlation between family type and attitude of rural youth towards village development activities.

This is clearly shows that family type and attitude of rural youth were positive and highly significantly related with each other due to the less restriction of youth in nuclear family. Thus family type has highly significant influence over the attitude of rural youth towards village development activities.

\section{Family size and attitude}

The data in the Table 2 revealed that, there was a positive and highly significant correlation between family size and attitude of rural youth towards village development activities.

It could be concluded that family size and attitude were positive and highly significantly related with each other. More number of family sizes might be having more social contacts and use of sources of information.
Thus family size has highly significant influence over the attitude of rural youth towards village development activities.

\section{Annual income and attitude}

The data in the Table 2 observed that, there was a positive and highly significant correlation between annual income and attitude of rural youth towards village development activities.

From this result it can be said that the annual income determines the economic status of the respondents. This clearly helps in developing the attitude of rural youth.

Annual income of the respondents therefore, could establish positive and highly significant relationship with attitude of rural youth towards village development activities.

\section{Use of sources of information and attitude}

The data in the Table 2 pointed out that, there was a positive and highly significant correlation between use of sources of information and attitude of rural youth towards village development activities. 
An individual develops an attitude if he has got an opportunity to expose with more number of sources of information. A respondents who has use of more source of information has higher exposure to various media and it enriches their level of attitude. Use of more sources of information helps in clarifying the contents of the message received through any source. It might be the reason that use of source of information could express the positive and highly significant relationship with attitude of rural youth towards village development activities.

The findings reported by Rashid Md.Mamunur and QijieGao (2012) and Kitturmath et al., (2014).

\section{Extension contact and attitude}

The data in the Table 2 revealed that, there was a positive and highly significant correlation between extension contact and attitude.

It is obvious that respondents with higher level of contact with extension agency are generally favorably predisposed to gather more information, develop skills and other factors relating to particular aspect of village development consequently and level of attitude. Thus, in this study positive and significant relationship must have been established between contact with extension personnel, agency and attitude.

The findings of the study were in accordance with the Uddin et al., (2008), Kitturmath et al., (2014).

\section{Achievement motivation and attitude}

The data in the Table 2 concluded that, there was a positive and highly significant correlation between achievement motivation and attitude of rural youth towards village development activities. Achievement is related to the knowledge and attitude of youth that motivate respondent to achieve goals that decided by them, due to education there increase in knowledge and attitude that's why achievement motivation had positive and significant relationship with attitude.

This finding is in the line with the finding of Kitturmath et al., (2014)

The study indicated that, profile of the respondents were middle age group, educated up to post graduate level, belongs Hindu religion, belongs Nuclear family type, medium family size, medium annual income, medium use of sources of information, medium extension contact and medium achievement motivation. Correlation coefficient (r) age, education, religion, family type, family size, annual income, use of sources of information, extension contact, and achievement motivation found to be had positive and highly significant relationship with attitude of rural youth towards village development activities.

\section{References}

Buragohain, Moromi, Bordoloi Nagen, Lego, Inne. Hussian, H.M. and Saikia, Dipanjali. 2018. A Study on Relationship between Extent of Participation in Decision Making Activities, With Socio-economic and Psychological Characteristics of Rural Youths towards Farming in Jorhat District of Assam. International Journal of Agriculture Sciences, 10 (3): 51155117.

Buragohain, N., Bordoloi and Lego, I. 2018. A Study Showing the Relationship betw een Extent of Participation of Rural You ths towards Management Activities Rel ating to Farming with Socioeconomic a nd Psychological Characteristics in Jorh 
at District of Assam, India. Int. J. Curre nt. Microbiology. App. Sci., 7 (1): 28822886.

Gandhale Amit, Khalage M.I., and Deshmukh J.M. (2018) Profile Analysis of Aspired Rural Youth. Multilogic in Science, 7 (25): 60-62.

Kitturmath, M.G., Suradkar, D. D., Bharamagoudar, M.V., and Thombre, B. M. (2014) Study of Demographic Profile and Attitude of Rural Youth towards Rural Development Activities. Trends in Biosciences, 7 (11): 10431046.

Laogun, E. A. 2002. Rural Youth Training Needs for Rural Community Development. Nigerian Journal of Rural Sociology, 3(2): 57-63.

Tekale, V.S., Mali, M.D. and Shaikh, J.I. 2015. Aspirations of rural youth towards self-development. Adv. Res. J. Soc. Sci., 6 (1): 36-41.

\section{How to cite this article:}

Anarase, M.S., D.D. Suradkar and Kamble, V.B. 2018. Relationship between Profile of Rural Youth and Attitude towards Village Development Activities. Int.J.Curr.Microbiol.App.Sci. 7(08): 2923-2929. doi: https://doi.org/10.20546/ijcmas.2018.708.309 